DOI: $10.21608 / z v j z .2016 .7872$

\title{
Effect of Insecticide "Chlorpyrifos" on Immune Response of Oreochromis niloticus
}

\author{
Zeinab M. El-Bouhy, Gamal El- Nobi, Rasha M. Reda* and Rowida E. Ibrahim
}

Fish Diseases and Management Department, Faculty of Veterinary Medicine, Zagazig University, 44511, Egypt

Article History: Received: 29/9/2016 Received in revised form: 9/11/2016 Accepted: 6/12/2016

\begin{abstract}
This study was carried out to determine the level of Chlorpyrifos (CPF), an organophosphorus insecticide, in water of Abbassa and Sahl El-Hussinia fish farms and investigate the sub lethal concentration of this pesticide on immune response of Oreochromis niloticus (O. niloticus). Water samples were collected from Abbassa and Sahl El-Hussinia fish farms and analyzed using Gas chromatograph (GC) for detection of Chlorpyrifos level. Two hundred and ninety $O$. niloticus with average body weight $(35 \pm 0.5 \mathrm{~g})$ were collected from Abbassa fish hatchery, Sharkia Governorate, Egypt. One hundred and seventy of these fish were used for the determination of acute toxicity of Chlorpyrifos, while, another 120 fish were used for the determination of the effect of different sub lethal concentrations of Chlorpyrifos $(1 / 8,1 / 20$ and $1 / 43$ of $96 \mathrm{~h} \mathrm{LC}_{50}$ ) on the immune response of $O$. niloticus. It was found that; the levels of Chlorpyrifos in Abbassa and Sahl El-Hussinia fish farms were 0.008 and $0.0016 \mathrm{mg} / \mathrm{L}$, respectively. The $\mathrm{LC}_{50}$ value of Chlorpyrifos was $0.07 \mathrm{mg} / \mathrm{L}$. Sub-lethal concentration of Chlorpyrifos altered the non-specific immunological parameters (namely, total globulin, immunoglobulin M (IgM), lysozyme, nitric oxide, phagocytic activity) and interlukin-1 $\beta$ (IL-1 $\beta$ ) of $O$. niloticus. It could be concluded that water of Abbassa and Sahl El-Hussinia fish farms have had detectable residue levels of CPF, which was altered the immunological status of O. niloticus.
\end{abstract}

Keywords: Chlorpyrifos, Oreochromis niloticus, Residues, Abbassa, Sahl El-Hussinia

\section{Introduction}

Aquaculture is considered one of the most important food sources and nutrition for hundred millions of people all over the world. Now, aquaculture provides half of human needs for fish consumption, while, by 2050 , fish production is expected to provide nutrition and food security for 9.7 billion of people [1]. Fish culture in Egypt depends mainly on agriculture drainage and wastewater that leads to water pollution by agriculture wastes such as pesticides. The increased amounts of pesticide pollutants are harmful to fish leads to sudden mortalities, while lower levels of pollutants result in accumulation in the aquatic environment leading to other hazards such as immunosuppression, reduced metabolism and damage of the gill tissue [2].

Aquatic pollution is still a problem in many freshwater and marine environments. It had harmful effects for the health of the aquatic organisms especially the fish. The effects of pollutants can be either lethal or sub- lethal [3]. Pesticides enter water sources through the direct application in aquatic systems for eradication of insects, herbs and mollusks. While, the indirect arrival was by erosion from agricultural lands and agricultural wastewater infiltration and eventually washed into deep-water environments and ecosystem [4].

Chlorpyrifos (CPF) is an organophosphate insecticide that is used widely in most regions. In agriculture, it is used to control insect pest on fruits and grains as a foliar spray or applied directly to soil. The CPF pollute natural water through air drift or surface runoff, leading to accumulation in living organisms in water and mainly in fish [5]. This study aimed to determine the level of CPF in water samples from Abbassa and Sahl El-Hussinia fish farms and to detect the effect of different sub-lethal concentrations of $\mathrm{CPF}$ toxicity on general health conditions and the immune response of Oreochromis niloticus (O. niloticus). 


\section{Material and methods}

\section{Water samples}

Water samples were collected from Abbassa and Sahl El-Hussinia fish farms for the determination of CPF level using Gas chromatography apparatus (GC) at the Central Agricultural Pesticides Laboratory (CAPL), Dokki, Egypt.

\section{Determination of the $\mathrm{LC}_{50}$}

One hundred and seventy fish were used in this experiment; one hundred apparently healthy Oreochromis niloticus with an average body weight $(35 \pm 0.5 \mathrm{~g})$ were obtained from Abbassa fish hatchery, Sharkia, Egypt. Fish were used for the determination of $\mathrm{LC}_{50}$ of 96 $\mathrm{h}$ of CPF. The fish were left in fully prepared glass aquaria (each, $80 \times 40 \times 30 \mathrm{~cm}$ capacity) for 15 days before the beginning of the experiment for acclimation. After this period, the fish were divided into 10 equal groups to determine the zero and hundred percentage of mortalities. All groups of fish were exposed to different concentrations of CPF (Table 1). To determine the actual $\mathrm{LC}_{50}$, another $70 O$. niloticus were adapted and then they were divided into 7 equal groups. The groups were exposed to various concentrations of $\mathrm{CPF}$ $(0.02,0.04,0.06,0.08,0.1,0.12$ and 0.14 $\mathrm{mg} / \mathrm{L}$ ) in groups from 1 to 7 , respectively for a period of $96 \mathrm{~h}$. The $96 \mathrm{lc}_{50}$ was determined according to Behrens and Karber [6]. The groups were observed at $12 \mathrm{~h}$ interval up to 96 h.

Table 1: Estimation of zero and hundred \% mortalities in Nile tilapia exposed to different levels of Chlorpyrifos (After 96 hours)

\begin{tabular}{|c|c|c|c|c|c|c|c|}
\hline \multirow{2}{*}{$\begin{array}{l}\text { Groups } \\
(\mathrm{N}=10)\end{array}$} & \multirow{2}{*}{$\begin{array}{c}\text { Concentration of } \\
\text { Chlorpyrifos } \\
(\mathrm{mg} / \mathrm{L})\end{array}$} & \multicolumn{4}{|c|}{ Mortality number during 96 hours } & \multirow{2}{*}{$\begin{array}{c}\text { Total } \\
\text { number }\end{array}$} & \multirow[t]{2}{*}{$\%$} \\
\hline & & $1^{\text {st }}$ day & $2^{\text {nd }}$ day & $3^{\text {rd day }}$ & $4^{\text {th }}$ day & & \\
\hline 1 & 0 & 0 & 0 & 0 & 0 & 0 & 0 \\
\hline 2 & 0.02 & 0 & 0 & 0 & 0 & 0 & 0 \\
\hline 3 & 0.04 & 0 & 1 & 2 & 2 & 5 & 50 \\
\hline 4 & 0.06 & 0 & 1 & 3 & 2 & 6 & 60 \\
\hline 5 & 0.08 & 0 & 2 & 2 & 2 & 6 & 60 \\
\hline 6 & 0.1 & 0 & 3 & 2 & 1 & 6 & 60 \\
\hline 7 & 0.12 & 0 & 2 & 4 & 1 & 7 & 70 \\
\hline 8 & 0.14 & 0 & 3 & 4 & 3 & 10 & 100 \\
\hline 9 & 0.16 & 0 & 5 & 2 & 3 & 10 & 100 \\
\hline 10 & 0.18 & 0 & 6 & 4 & 0 & 10 & 100 \\
\hline
\end{tabular}

The effect of Chlorpyrifos chronic toxicity on general health condition and immune response of $O$. niloticus

One hundred and twenty apparently healthy fish were obtained from Abbassa fish hatchery, Sharkia Governorate, Egypt, to determine the effect of chronic toxicity of CPF on the immune response of $O$. niloticus. The fish with an average body weight $(35 \pm 0.05 \mathrm{~g})$ were allocated into four groups; each group had three replicates (10 fish replicate ${ }^{-1}$ ). Group 1: control group (not treated with $\mathrm{CPF}$ ), group 2 were exposed to $1 / 896 \mathrm{~h} \mathrm{LC}_{50}(0.008 \mathrm{mg} / \mathrm{L})$ of CPF; group 3 were exposed to $1 / 2096 \mathrm{~h}$ $\mathrm{LC}_{50}(0.0035 \mathrm{mg} / \mathrm{L})$ of $\mathrm{CPF}$ and group 4 were exposed to $1 / 4396 \mathrm{~h} \mathrm{LC}_{50}(0.0016 \mathrm{mg} / \mathrm{L})$ of $\mathrm{CPF}$. The water parameters were monitored and were kept within the recommended ranges during the experiment (water temperature $=$ $25.5 \pm 0.5 ; \mathrm{pH}=7.2 \pm 0.5 ;$ ammonia $=0.02 \pm 0.001$ $\mathrm{mg} / \mathrm{L}$ and nitrite $=0.017 \pm 0.001 \mathrm{mg} / \mathrm{L})$ [7]. Water exchange was performed twice weekly with maintenance of the insecticide level in the water. The fish were fed on basal diet obtained from Fish Research Unit, Faculty of Veterinary Medicine, Zagazig University; at a rate of $3 \%$ of body weight, two times daily. Clinical signs and postmortem lesions were recorded during the experimental period (one month). 


\section{Innate immune response parameters and serum proteins level}

Blood samples (3 samples/group) were obtained by puncturing the caudal blood vessels after 15 and 30 days of the experiment. The blood samples were collected without heparin for serum separation and were centrifuged at $3000 \mathrm{rpm}$ for $15 \mathrm{~min}$ then stored at $-20^{\circ} \mathrm{C}$ until analysis. Serum total protein, albumin and globulin levels were assayed [810]. Immunoglobulin M (IgM) was determined using ELISA Kit. Lysozyme activity, nitric oxide, phagocytic activity were also determined [11-13].

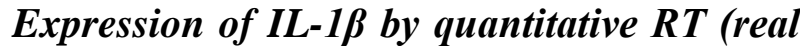 time)-PCR.}

Total RNA was extracted from the spleen tissue (3 samples/group) of all fish groups after 15 and 30 days of the experiment using easy-REDTM following the manufacturer protocol (iNtRON Biotechnology, South Korea). The complementary DNA was synthesized following the manufacturer's instructions of a Quantitect ${ }^{\circledR}$ Reverse Transcription kit (Qiagen, Germany). Quantitative real-time PCR analysis was performed using SYBR green PCR master mix (StepOnePlus, Applied Biosystem, USA). The target gene chosen was IL-1 $\beta$ (F: 5'-TGC TGA GCA CAG AAT TCC AG-3'; R: 5'-GCT GTG GAG AAG AAC CAA GC-3'); and EF-1 $\alpha$ as an internal standard (F: 5'-CCT TCA ACG CTC AGG TCA TC-3'; R: 5'-TGT GGG CAG TGT GGC AAT C-3') [14, 15]. The thermal cycling conditions were initial denaturation at $94{ }^{\circ} \mathrm{C}$ for $5 \mathrm{~min}, 40$ cycles of amplification (DNA denaturation at $94^{\circ} \mathrm{C}$ for $15 \mathrm{sec}$, annealing at $62^{\circ} \mathrm{C}$ for $30 \mathrm{sec}$, extension at 72 ${ }^{\circ} \mathrm{C}$ for $30 \mathrm{sec}$ ). The final extension at $62^{\circ} \mathrm{C}$ for $1 \mathrm{~min}$. To estimate the variation of gene expression on the different samples, the CT of each sample was compared with that of the control group according to the " $\Delta \Delta \mathrm{Ct}$ " method using the following ratio: $\left(2^{-\Delta \Delta c t}\right)$. Whereas $\Delta \Delta \mathrm{Ct}=\Delta \mathrm{Ct}$ reference $-\Delta \mathrm{Ct}$ target. $\Delta \mathrm{Ct}$ target $=\mathrm{Ct}$ control $-\mathrm{Ct}$ treatment and $\Delta \mathrm{Ct}$ reference $=\mathrm{Ct}$ control- $\mathrm{Ct}$ treatment.

\section{Statistical analyses}

The data were analyzed by comparing the means differences using analysis of variance (One Way ANOVA) using the SPSS 16.0 computer program. A P- value of $\leq 0.05(\mathrm{P} \leq$ 0.05 ) was considered statistically significant.

\section{Results and Discussion}

\section{Cholrpyrifos level in collected water samples}

Cholrpyrifos level detected in the water samples collected from Abbassa and Sahl ElHussinia fish farms were 0.008 and 0.0016 $\mathrm{mg} / \mathrm{L}$, respectively. The detectable levels of CPF in the water may be attributed to the escape of this insecticide from agriculture drainage. Nearly similar results were observed by Malhat and Nasr [16] who estimated the residues of organophosphorus pesticides in water samples from different tributaries of the River Nile in Egypt, which are El Menofiya canal water supplies (El Sarsawia, El Bagoria and Bahr Shebin), in addition to El Embaby, El Menofi and Miet Rabiha drainage canals using Gas chromatograph. Only Chlorpyrifosmethyl (41.53 ng $\left.{ }^{-1}\right)$ and Prothiphos (30.03 ng $1^{-1}$ ) were detected in El-Embaby drain.

\section{Chlorpyrifos $96 \mathrm{~h} \mathrm{LC} \mathrm{C}_{50}$ in Nile tilapia}

The results showed that $96 \mathrm{~h} \mathrm{LC}_{50}$ of $\mathrm{CPF}$ in Nile tilapia was $0.07 \mathrm{mg} / \mathrm{L}$ (Table, 2). Fish showed abnormal swimming behavior, nervous manifestations, erected pectoral fin (Figure 1A) and erythema on skin with fin rot (Figure 1B) and asphyxia before death. The recorded clinical signs may be attributed to that CPF inhibit acetyl choline esterase by its binding capacity to the enzyme active site, that plays an important role in neurotransmission [5]. This enzyme makes rapid hydrolysis of neurotransmitter acetylcholine to choline and acetate 7 . The inhibitory effects lead to nervous manifestations on fish. In another study, it is reported that the $96 \mathrm{~h} \mathrm{LC}_{50}$ of CPF in Tilapia guineensis was $0.002 \mathrm{mg} / \mathrm{L}$, with increase in operculum beat frequency and tail beat frequencies by increase the exposure time and concentration [17]. In addition, Muttappa et al. [18] mentioned that the $96 \mathrm{~h} \mathrm{LC}_{50}$ for CPF in $O$. mossambicus was $0.022 \mathrm{ppm}$. The differences in the value of $\mathrm{LC}_{50}$ may be attributed to species sensitivity, life stage and environmental factors. 
Table 2: Actual estimation of $96 \mathrm{~h}$ mortalities $\mathrm{LC}_{50}$ in Nile tilapia exposed to different levels of Chlorpyrifos

\begin{tabular}{|c|c|c|c|c|c|c|}
\hline $\begin{array}{l}\text { Groups } \\
(\mathrm{N}=\mathbf{1 0})\end{array}$ & $\begin{array}{c}\text { Concentration } \\
(\mathrm{mg} / \mathrm{L})\end{array}$ & $\begin{array}{c}\text { Number of } \\
\text { dead fish at } 96 \\
\text { hours }\end{array}$ & $\mathbf{a}$ & b & $\mathbf{a x b}$ & $\Sigma \mathbf{a x b}$ \\
\hline 1 & 0.02 & 0 & & & & \\
\hline 2 & 0.04 & 5 & 0.02 & 2.5 & 0.05 & \\
\hline 3 & 0.06 & 6 & 0.02 & 5.5 & 0.11 & \\
\hline 4 & 0.08 & 6 & 0.02 & 6 & 0.12 & \\
\hline 5 & 0.1 & 6 & 0.02 & 6 & 0.12 & \\
\hline 6 & 0.12 & 7 & 0.02 & 6.5 & 0.13 & \\
\hline \multirow[t]{2}{*}{7} & 0.14 & 10 & 0.02 & 8.5 & 0.17 & \\
\hline & & & & & & 0.7 \\
\hline
\end{tabular}

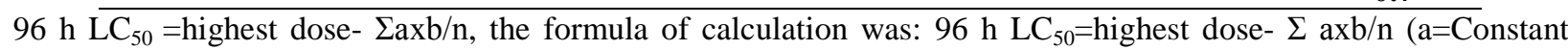
factors between two successive dose, $b=$ the mean of dead fish in each group, $c=$ the number of fish in each group, $\Sigma \mathrm{axb}=$ sum of axb, $\mathrm{n}=$ Number of fish in each groups $=0.140 .7 / 10=0.07 \mathrm{mg} / \mathrm{L}$

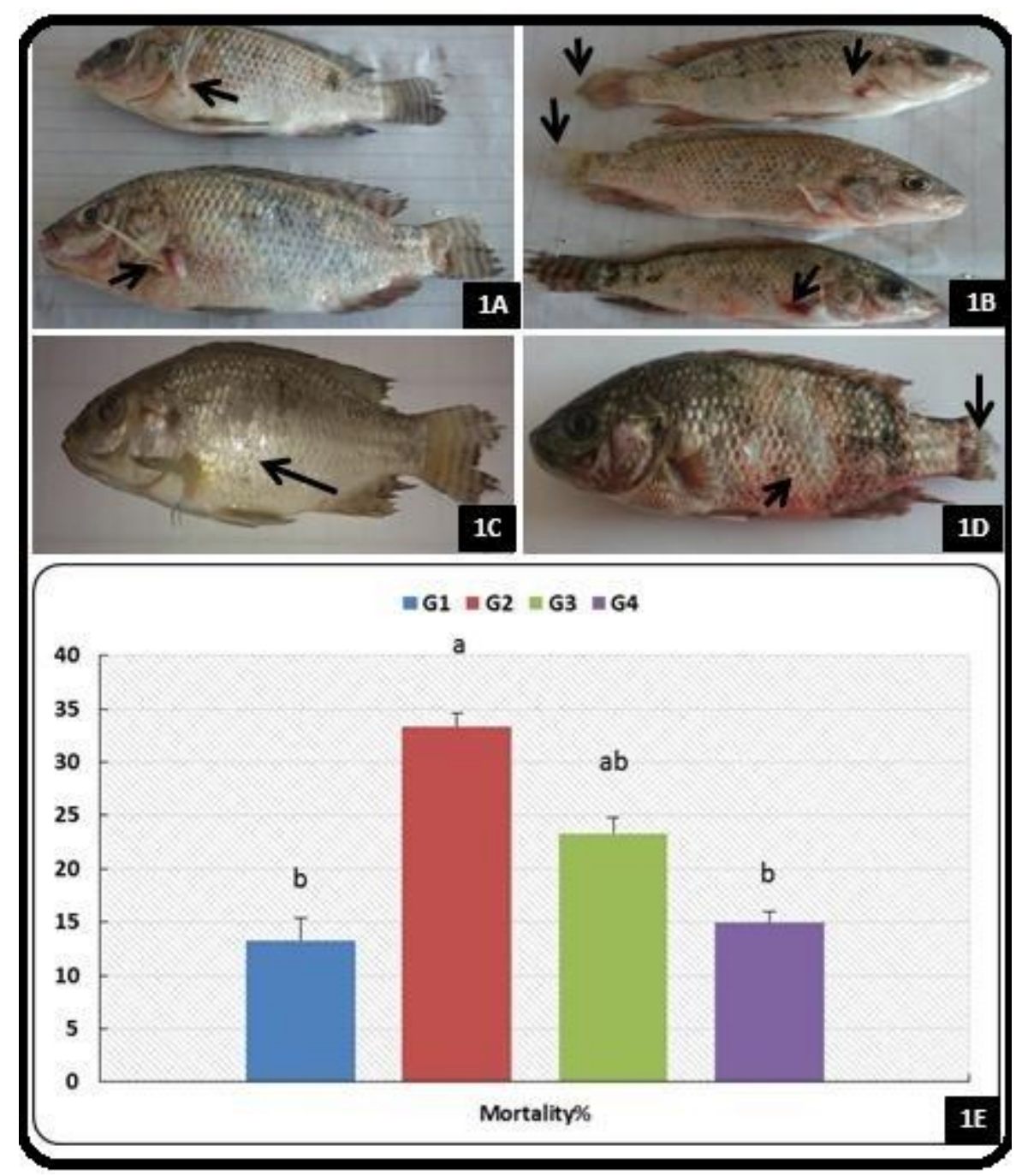

Figure 1: Clinical signs of $\boldsymbol{O}$. niloticus exposed to A). Acute toxicity of Chlorpyrifos that showing pectoral fin erection and B). Fin rot and erythema. C). O. niloticus that exposed to $1 / 2096 \mathrm{~h} \mathrm{LC} \mathrm{C}_{50}$ of Chlorpyrifos suffered from fin rot and increase of mucus secretions D). $O$. niloticus that exposed to $1 / 896 \mathrm{~h} \mathrm{LC}_{50}(0.008 \mathrm{mg} / \mathrm{L})$ of Chlorpyrifos suffered from erythema on skin and fin rot. E). Mortality rate at the end of experimental period (30 days). The bars with different superscripts (a, b, and c) are significantly different. 
The chronic toxicity effect of Chlorpyrifos on general health condition and non-specific immune parameters of $O$. niloticus

Fish exposed to $1 / 896 \mathrm{~h} \mathrm{LC}_{50}(0.008$ $\mathrm{mg} / \mathrm{L}$ ) of $\mathrm{CPF}$ (group 2) showed significant high mortality rate with signs of erythema on skin and fin rot followed by group 3 (fish exposed to $1 / 2096 \mathrm{~h} \mathrm{LC}_{50}, 0.0035 \mathrm{mg} / \mathrm{L}$ of $\mathrm{CPF}$ ) with fin rot and increased mucus secretions compared to control group (Figure
1C, 1D and 1E). Increased mortalities with increased concentrations of CPF was observed. Chindah et al. [17] who found that Tilapia guineensis exposed to sub lethal concentrations of CPF $(0.0125 \mathrm{mg} / \mathrm{L} ; 0.025$ $\mathrm{mg} / \mathrm{L} ; 0.05 \mathrm{mg} / \mathrm{L}$ and $0.1 \mathrm{mg} / \mathrm{L}$ ) showed increased mortality rates with elevated concentration level and exposure time obtained similar results.
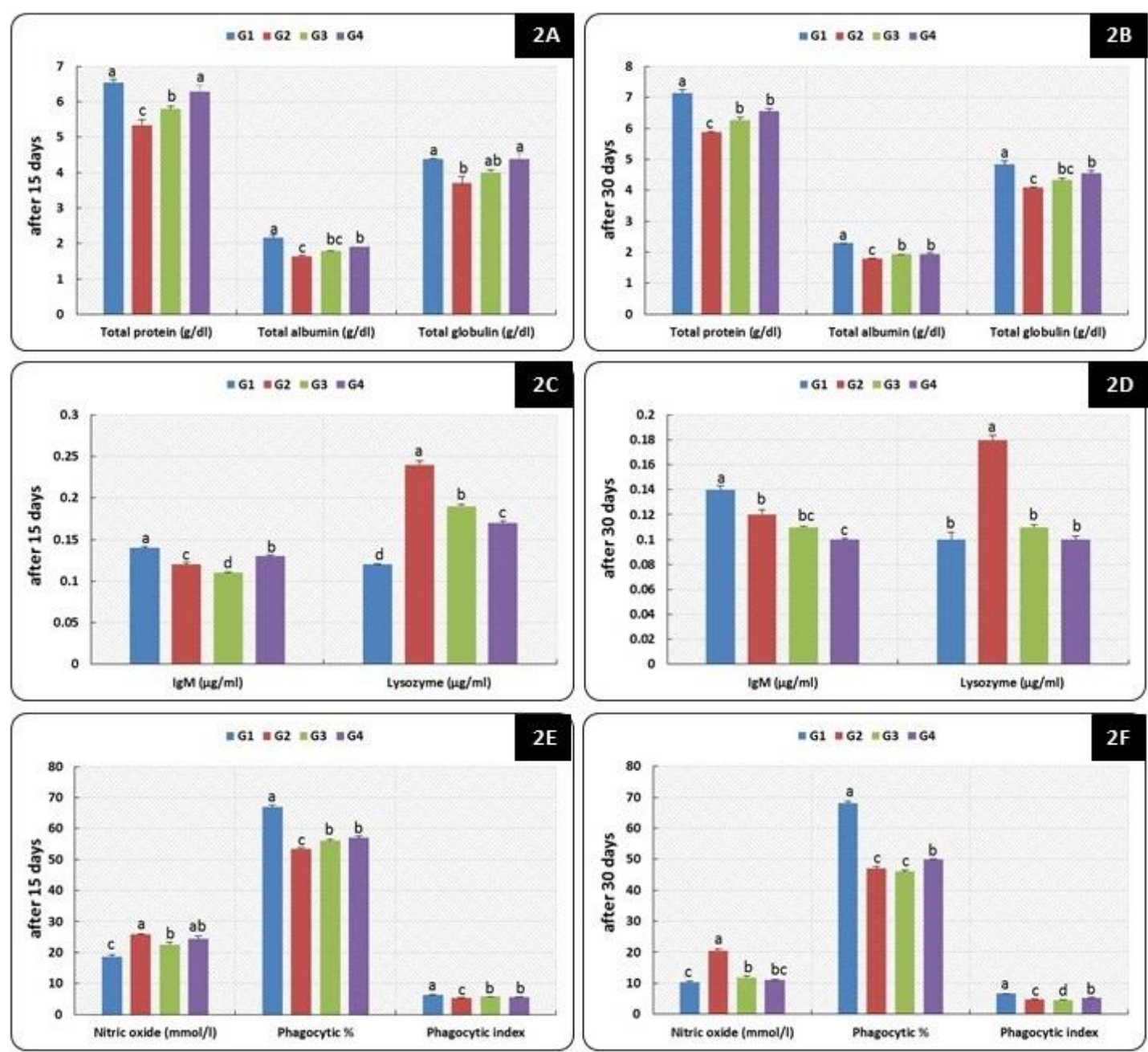

Figure 2: Effect of the different concentrations of Chlorpyrifos on A and B). Total serum protein (g/dl), albumin (g/dl) and globulin (g/dl) of $O$. niloticus after 15 and 30 days, respectively. C and $\mathrm{D})$. $\mathrm{IgM}(\mu \mathrm{g} / \mathrm{mL})$ and lysozyme activity $(\mu \mathrm{g} / \mathrm{ml})$ of $O$. niloticus after 15 and 30 days, respectively. $E$ and $F)$. Nitric oxide (mmo/L), phagocytic \% and phagocytic index of $O$. niloticus after 15 and 30 days, respectively. The bars with different superscripts (a, b, c and d) are significantly different $(P<0.05)$. 
The fish groups exposed to $1 / 8$ and $1 / 20$ $\mathrm{LC}_{50} 96 \mathrm{~h}$ of CPF (groups 2 and 3) showed decreased levels of serum total proteins, albumin and globulin after 15 and 30 days of the experiment. While, group 4 (fish exposed to $1 / 4396 \mathrm{~h} \mathrm{LC} \mathrm{LC}_{50}, 0.0016 \mathrm{mg} / \mathrm{L}$ of $\mathrm{CPF}$ ) showed no significant differences in the levels of serum total proteins, globulin and decrease level of albumin compared with control after 15 days of the experiment. The same group showed diminished levels of total proteins, albumin and globulin after 30 days of the experiment (Figure 2A and 2B). Low values of total proteins may be attributed to inhibition of RNA synthesis by CPF leading to disturbing the protein metabolism and inhibition of hepatic metabolizing enzymes. Stress conditions due to pesticide pollution resulted in catabolism of the proteins to provide energy to withstand these stress conditions with degradation of proteins into free amino acids for different metabolic activities [19, 20]. These results are in agreement with those obtained by Ramesh and Sarvanan [21] in $C$. carpio exposed to CPF and results obtained by Bhanu, and Deepak [22] who reported a decrease in the serum protein in $C$. carpio exposed to sub lethal concentration of Cypermethrin for 28 days. The decreased serum albumin and globulin levels due to $\mathrm{CPF}$ exposure may be due to liver damage caused by this pesticide or to the decrease in protein synthesis in the liver [22].

The IgM level decreased after 15 and 30 days of the experiment in groups 2, 3 and 4 compared with the control group (Figure 2C and 2D). The IgM is the most important immunoglobulin in fish, which is altered by pesticide pollution; lowered levels of IgM may be attributed to the effect of CPF as a stress factor on fish leading to diminished levels of IgM. These results coincide with that recorded in plasma IgM level in $O$. niloticus and $C$. carpio, which were exposed to $0.051 \mathrm{mg} / \mathrm{mL}$ and $75 \mu \mathrm{g} / \mathrm{L}$ of $\mathrm{CPF}$, respectively [23, 24]. Concerning the level of lysozyme and nitric oxide, increased lysozyme level in groups 2,3 and 4 after 15 days of the experiment compared with control group was observed (Figures 2C, 2D, 2E and 2F). After 30 days, the lysozyme level was significantly increased in groups 2 and 3, while there were no significant differences in group 4 compared to the control group. The lysozyme is one of the humoral innate immune factors; which is considered as a natural antibiotic of fish [25]. O. niloticus exposed to CPF at a rate of 0.102 and $0.255 \mathrm{mg} / \mathrm{L}$ revealed an increase in the activity of lysozyme level; but the lower concentration $(0.051 \mathrm{mg} / \mathrm{mL})$ of such pesticide did not produce any change on the lysozyme activity [26]. However, Wang et al. [27] reported that exposure of $C$. carpio to CPF (75 $\mu \mathrm{g} / \mathrm{L}$ ) decreased the levels of lysozyme in plasma and spleen.

Increased level of nitric oxide under the influence of CPF may be attributed to that; fish body produces protective mechanism against the stress of pesticide. This result is in agreement with that obtained by DíazResendiz et al. [25] who reported increased production of nitric oxide significantly after exposure to pesticide. In addition, $\mathrm{Xu}$ et al. [26] reported that $\mathrm{CPF}$ (1.16, 11.6 and 116 $\mu \mathrm{g} / \mathrm{L}$ ) induce an increase in the level of nitric oxide in $C$. carpio. The phagocytic $\%$ and phagocytic index were significantly decreased in all experimental groups compared with control after 15 and 30 days of the experiment (Figure 2E and 2F). This may be attributed to that CPF suppress the action on fish phagocytic cells as the pollution by pesticide is considered to be abiotic stress factor. This result is nearly similar with that obtained by Girón-Pérez et al. [28] who reported that exposure of Nile tilapia to Diazinon decreased the phagocytic index of mononuclear cells. 


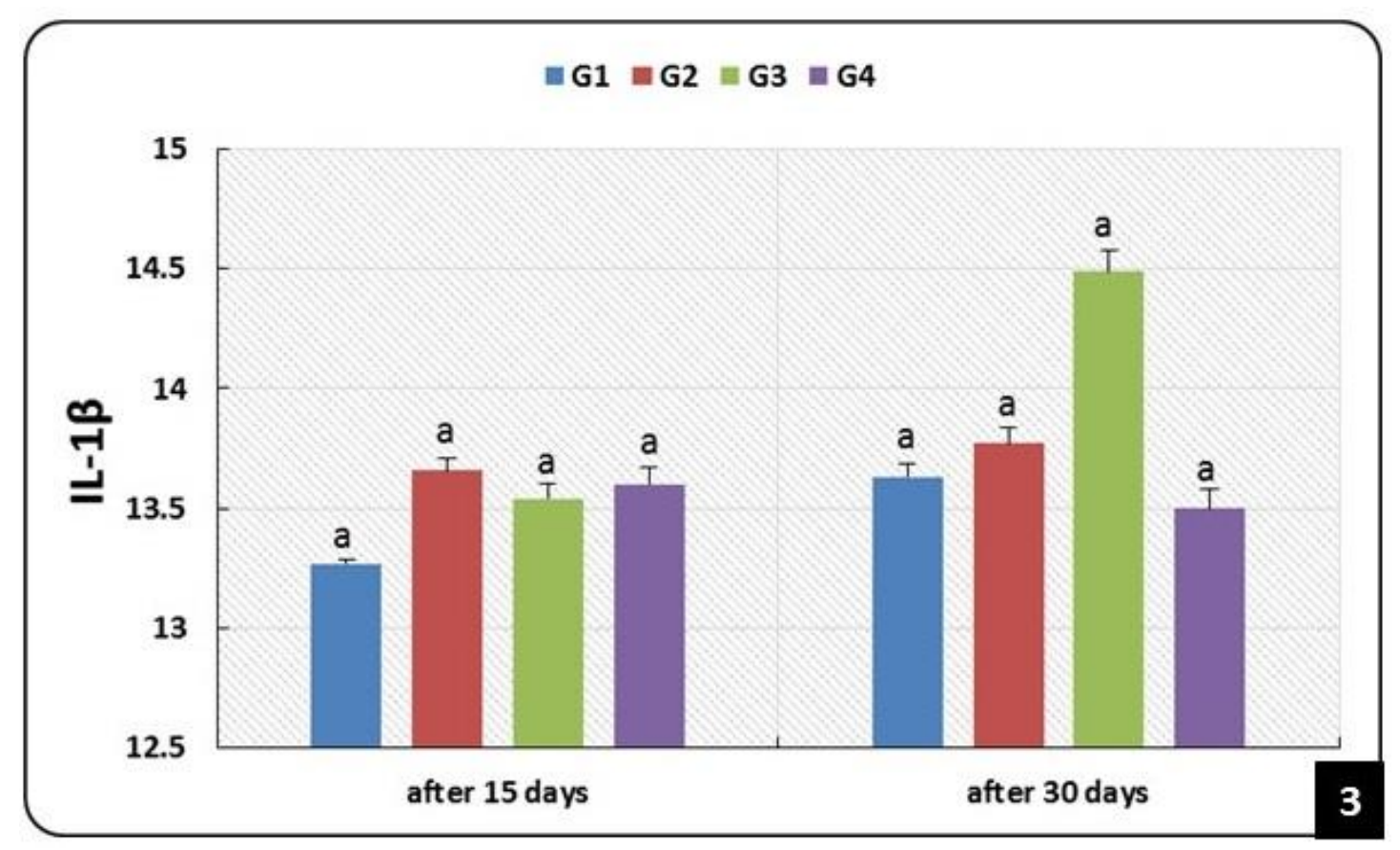

Figure 3: Effect of the different concentrations of Chlorpyrifos on IL-1ß gene expression of $O$. niloticus after 15 and 30 days (G: Group).

The mRNA expression level of the immune genes IL-1 $\beta$ is shown in Figure 3, which indicated insignificant difference in the expression of IL- $1 \beta$ between the experimental groups but with slight increase in G2 and G3 after 15 and 30 days of the experiment, respectively. The IL-1 $\beta$ is one of the cytokines in fish that respond to water pollution by pesticide. Similar results were obtained by Wang et al. [29] who reported that exposure of C. carpio to CPF $(1.16,11.6$ and $116 \mu \mathrm{g} / \mathrm{L})$ for $24 \mathrm{~h}$ evoked increased expression of mRNA of IL-1 $\beta$.

\section{Conclusion}

It could be concluded that water of Abbassa and Sahl El-Hussinia fish farms have had detectable residue levels of CPF. This insecticide has a toxic effect and altered the immunological parameters of $O$. niloticus.

\section{Conflict of interest}

The authors declare no conflict of interest.

\section{References}

[1] FAO (Food and Agriculture Organization of United Nations) (2016): The state of world fisheries and aquaculture. Fisheries and Aquaculture Department, Rome.

[2] Austin, B. (1999): The effects of pollution on fish health. J Appl Microb, 85 (S1): 2348-2428.

[3] Sures, B. (2008): Environmental Parasitology. Interactions between parasites and pollutants in the aquatic environment. Parasite, 15(3): 434-438.

[4] Venkataraman, G.V. and Sandhya Rani, P.N. (2013): A cute toxicity and blood profile of freshwater fish, Clarias batrachus (Linn.) exposed to Malathion. JAIR, 2(3) 200-204.

[5] Deb, N. and Das, S. (2013): Chlorpyrifos Toxicity in Fish: A Review. Curr World Environ, 8(1): 77-84.

[6] Behrens, B. and Karber, (1953): Determination of $\mathrm{LC}_{50}$. Arch Fur Exp Path Und Pharm, 28-177.

[7] APHA (1998): Standards methods for examination of water and wastewater. (American Health Association) American Public Health Association Inc, Washington DC 20th Edition.

[8] Gornal, A.G.; Bardwil, C.J. and David, M.M. (1946): Determination of serum proteins by mean of the biuret reaction. $\mathbf{J}$ Biol Chem, 177: 751-766. 
[9] Weichselbaum, T.E. (1946): An accurate and rapid method for the determination of protein in small amounts of blood, serum and plasma. Am J Clin Pathol, 7: 40-49.

[10] Doumas, B.T.; Waston, W.A. and Biggs, H.G. (1971): Quantitative colorimetric determination of albumin in serum or plasma. Clin Chem Act, 31: 87-91

[11] Mohrig, W.V. and Messner, B. (1968): Immunreaktionen bei Insekten. I. Lysozym als grundlegender antibakterieller Faktor im humoralen Abwehrsystem der Insekten. Biol Zbl, 4: 439-470.

[12] Sun, J.; Zhang, X.; Broderick, M. and Fein, H. (2003): Measurement of nitric oxide production in biological system by using Griss Reaction Assay. Sensors, 3(8):276-284.

[13] Thompson, R.A. (1977): Techniques in clinical immunology. Publications P.201, USA.

[14] Gröner, F.; Ziková, A. and Kloas, W. (2015): Effects of the pharmaceuticals diclofenac and metoprolol on gene expression levels of enzymes of biotransformation, excretion pathways and estrogenicity in primary hepatocytes of Nile tilapia (Oreochromis niloticus). Comp Biochem Physiol C Pharmacol Toxicol, 167:51-57.

[15] Pirarat, N.; Pinpimai, K.; Endo, M.; Katagiri, T.; Ponpornpisit, A.; Chansue, N. and Maita, M. (2011): Modulation of intestinal morphology and immunity in Nile tilapia (Oreochromis niloticus) by Lactobacillus rhamnosus GG. Res Vet Sci, 91(3): 92-97.

[16] Malhat, F. and Nasr, I. (2013): Monitoring of organophosphorus pesticides residues in water from the Nile River tributaries, Egypt. AJWR,1(1):1-4.

[17] Chindah, A.C.; Sikoki, F.D. and Ijeoma, V.A. (2004): Toxicity of an Organophosphate Pesticide (Chlorpyrifos) on a common Niger Delta Wetland Fish -Tilapia guineensis (Blecker 1862). J Appl Sci Environ Mgt, 8 (2):11-17.

[18] Muttappa, K.; Reddy, H.R.V.; Padmanabha, A.; Shridhar, B.; Basavaraju, Y.; Prabhudeva, K.N.;
Gangadhar, G.; Rajanna, K. B. and Chethan, N. (2015): Chloropyrifos induced histopathological changes in the liver of tilapia (Oreochromis mossambicus). Int J Recent Sci Res, 6(8):5819-5823.

[19] Jenkins, G. and Smith, J. (2003): Effect of sub-lethal concentration of endosulphan on hematological and serum biochemical parameters in the carp Cyprinus carpio. Bull Environ Contam Toxicol,70(5): 993-947.

[20] Tripathi, V.K. and Yadav, R.K. (2015): Effect of Pesticide (Organophosphorus) on aquatic fish Labeo Rohita. Int J Chem Sci,13(2): 625-640.

[21] Ramesh, M. and Sarvanan, M. (2008): Hematological and biochemical responses in a freshwater fish Cyprinus carpio exposed to Chlorpyrifos. Int $\mathbf{J}$ Integr Biol, 3(1): 82-85.

[22] Bhanu, A.B. and Deepak,M. (2015): Impact of cypermethrin on biochemical aspects of clinical importance in the blood of freshwater fish Cyprinus carpio. J Entomol Zool Stud, 3(1):126-128.

[23] Diaz-Resendiz K.J.G. and Giron-Perez M.I. (2014): Effect of Chlorpyrifos on the immune response of Nile tilapia (Oreochromis niloticus). Revista Bio ciencias, 3(1):59-64.

[24] Li, X.; Liu, L.; Zhang, Y.; Fang, Q. and Li, Y. (2013): Toxic effects of Chlorpyrifos on lysozyme activities, the contents of complement $\mathrm{C} 3$ and $\operatorname{IgM}$, and $\mathrm{IgM}$ and complement $\mathrm{C} 3$ expressions in common carp (Cyprinus carpio L.). Chemosphere, 93(2): 428-433.

[25] Díaz-Resendiz, K.J.G.; Toledo-Ibarra, G.A. and Girón-Pérez, M.I. (2015): Modulation of Immune Response by Organophosphorus Pesticides: Fishes as a Potential Model in Immuno toxicology. J Immunol Res, 1-10.

[26] Xu, W.; Liu, W.; Lu, K.; Jiang, Y. and Li, G. (2011): Effect of trichlorfon on oxidative stress and hepatocyte apoptosis of Carassius auratusgibelio in vivo. Fish Physiol Biochem, 38(3):769-775.

[27] Wang, L.L.; Liu, T.; Wang, C.; Zhao, F.Q.; Zhang, Z.W.; Yao, H.D.; Xing, H.J. and Xu, S.W. (2013): Effects of 
atrazine and Chlorpyrifos on the production of nitric oxide and expression of inducible nitric oxide synthase in the brain of common carp (Cyprinus carpio L.). Ecotoxicol Environ Saf, 93:7-12.

[28] Girón-Pérez, M.I.; Zaitseva, G.; CasasSolis, J. and Santerre, A. (2008): Effects of diazinon and diazoxon on the lymph proliferation rate of splenocytes from Nile tilapia (Oreochromis niloticus): the immunosuppressive effect could involve an increase in acetylcholine levels. Fish Shellfish Immunol, 25(5):517-521.

[29] Wang, X.; Xing, H.; Li, X.; Xu, S. and Wang, X. (2011): Effects of atrazine and chloropyrifos on the mRNA levels of IL1 and IFN-2b in immune organs of common carp. Fish Shellfish Immunol. 31(1):126-133.

$$
\begin{aligned}
& \text { الملخص العربي } \\
& \text { تأثير مبيد "الكلوربيريفوس "على الاستجابة المناعية في اسماك البلطي النيلي. } \\
& \text { زينب مصطفي البوهي، جمال النوبي احمد، رشا محمد رضا*، رويدا السيد ابر اهيم } \\
& \text { قسم أمر اض ور عاية الاسماك، كلية الطب البيطري، جامعة الزئه الزقازيق }
\end{aligned}
$$

تهدف هذه الدر اسة الي تقدير مستوي المبيد الفسفوري الكلوربيريفوس في مياه مزارع العباسة وسهل الحسنية المستخدمة في الاستزر اع السمكي كذلك معرفة تأثثر التركيز تحت التهير المميت لهذا المبيد الحثري على على الاستجابة المناعية لأسماك البلطي النيلي. تم تجميع عينات مياه من مزارع العباسة وسهل الحسنية وتحليلها بواسطة جهاز الجاز كروماتوجراف افت الف تم استخدام مائتين

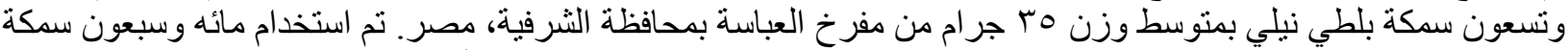

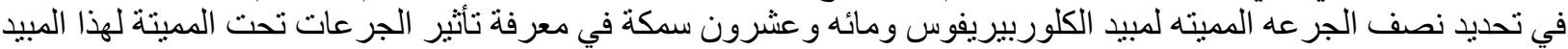

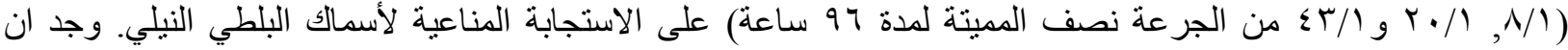

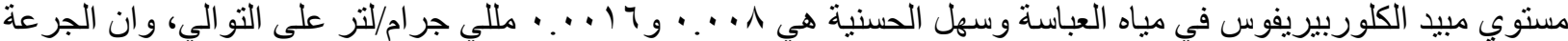

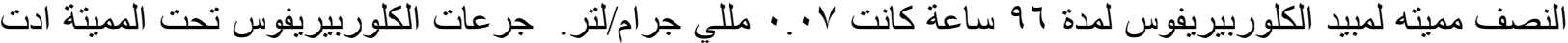

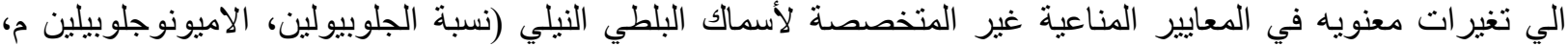

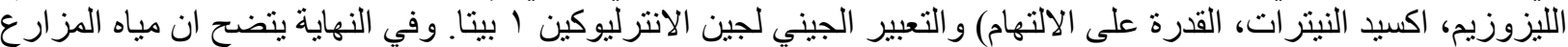

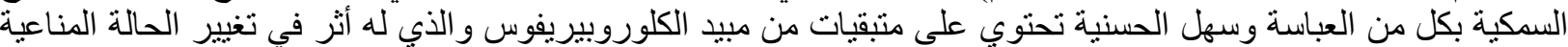
لأسماك البلطي النيلي. 